\title{
RESÚMENES DE TESIS: MAESTRÍA EN SALUD AMBIENTAL
}

\section{Evaluación del impacto de la exposición a mezclas de agroquímicos presentes en escorrentías de cultivos extensivos utilizando como biomarcadores el daño oxidativo y genotóxico en Cnesterodon decemmaculatus}

\author{
Néstor Abel Pautasso \\ nestorapautasso@gmail.com \\ Directora: Dra. María Fernanda Simoniello \\ Co-Directora: Dra. María Carolina Sasal \\ Lugar de realización: Laboratorio Toxicología y Bioquímica Legal, Facultad de Bioquímica y Ciencias Biológicas, Universidad Nacional \\ del Litoral y Estación Experimental Agropecuaria Paraná, Instituto Nacional de Tecnología Agropecuaria \\ Fecha de defensa: 04de junio de 2018
}

La contaminación difusa producida por agroquímicos en ambientes urbanos, periurbanos y rurales constituye una preocupación para nuestra sociedad. El objetivo de este trabajo fue evaluar el daño oxidativo y genotóxico causado por las escorrentías de plaguicidas en el pez Cnesterodon decemmaculatus (Jenyns, 1842), un organismo de amplia distribución en América del Sur. Los bioensayos se realizaron utilizando limnocorrales situados en un sistema natural superficial de agua que recibe los residuos de lotes bajo producción agrícola con rotación de cultivos, incluyendo maíz, trigo y soja. Se evaluó la actividad de la enzima antioxidante Catalasa, la peroxidación lipídica y el índice de daño al ADN utilizando el Ensayo Cometa en células branquiales de ejemplares controles y expuestos. Los especimenes fueron retirados del limnocorral 72 hs despues de un evento de lluvia con escorrentía sobre el tajamar. Durante este periodo se realizaron análisis de agua considerando residuos de plaguicidas, $\mathrm{pH}$ y temperatura. Los resultados mostraron diferencias estadísticamente significativas $(p<0,05)$ en el daño oxidativo y genotóxico sobre el epitelio branquial de los individuos expuestos a las escorrentías, en comparación con el control previamente determinado. Estos resultados muestran la utilidad de esta especie como centinela de contaminación por las mezclas de las escorrentías y la sensibilidad de los biomarcadores utilizados. Además, ponen de relieve la necesidad de comprender, prevenir y corregir los conflictos ambientales implementando medidas de mitigación y protección del ambiente asociado a las prácticas agrícolas para contribuir a la sostenibilidad y recuperación socio-agroambiental. 


\section{Evaluation of the impact of exposure to agrochemicals mixtures in extensive field runoff using bi- omarkers of oxidative and genotoxic damage in Cnesterodon decemmaculatus.}

Diffused contamination produced by agrochemicals in rural and surrounding urban environments constitutes an important concern for our society. The aim of this work was to evaluate oxidative and DNA damage caused by pesticide runoff on the fish Cnesterodon decemmaculatus (Jenyns, 1842), an extended distributed organism in South America. Bioassays were conducted using limnocorrals situated in a superficial natural water system which receives the residues of agricultural production under a system of crop rotation, including corn, wheat, and soybean. Was evaluated activity of antioxidant enzyme Catalase, lipid peroxidation and DNA damage index through the comet assay on epithelial gill cells of control and exposed fish. Specimens were taken from the limnocorral $72 \mathrm{~h}$ after a probed runoff event towards the lagoon. During these periods, water analysis was made for pesticide residues, $\mathrm{pH}$ and temperature. The results showed statistically significant differences $(p<0.05)$ on the gill epithelium DNA damage of the individuals exposed to the runoff, compared to the control value previously determined. These results show the utility of this species as a sentinel of contamination by the mixtures of runoff and the sensitivity of the biomarkers used. Also, highlight the need to understand, prevent and correct the environmental conflicts and slow down the deteriorating processes caused by the use of agrochemicals on extensive primary production systems, to contribute to the socio-agro environmental sustainability and recovery. 